Brit. F. vener. Dis. (1973) 49, 72

\title{
Genital infection in juvenile delinquent females
}

\author{
M. CALOENESCU, G. LAROSE, A. BIRRY, J. ROY, AND S. S. KASATIYA* \\ Laboratory Services, Quebec Department of Social Affairs, Canada
}

Infections due to Neisseria gonorrhoeae continue to increase at an alarming rate in most parts of the world at the same time as the development of a more liberal attitude to sexual matters. The highest incidence of gonorrhoea is normally found amongst the most sexually active group aged 20 to 29 years, but in Canada in 1970, 33 per cent. of female patients with gonorrhoea were below 20 years of age (Department of Health, 1971).

Trichomonas vaginalis is found in the urogenital tract of both males and females, and its mode of transmission is still a matter of controversy. Jirovec, Breindl, Kucera, and Sebek (1942) and Tsao (1969) believe it to be transmitted almost always by sexual intercourse, whereas Crowther (1962), Hawkins (1969), and others are reluctant to state that transmission of this parasite is exclusively sexual. The frequent association of $N$. gonorrhoeae and $T$. vaginalis in the same patient was first reported by King, Mascall, and Price (1936). In juvenile as well as in adult females, an associated trichomonal infection may be found in 40 to 50 per cent. of cases of gonorrhoea, whereas $N$. gonorrhoeae may be isolated in from 10 to 46 per cent. of cases of trichomoniasis (Tsao, 1969; Gallagher, 1970).

The role of Candida albicans in vaginal infections is variable. It is commonly found as a saprophyte in the intestines and the anorectal region and is considered to be a facultative pathogen. The exact mechanism of its pathogenicity is not yet known, but it is supposed that a change in the tissues or in the metabolism of the host (due, for example, to pregnancy, antibiotic therapy, antitrichomonal drugs, contraceptives, or diabetes mellitus) may disturb the natural balance of the flora of the vaginal tract and lead to pathological changes. Despite its frequent occurrence in women without symptoms, it is believed to be one of the commonest causes of genital symptoms, especially vaginal discharge (Catterall, 1971).

Received for publication May 16, 1972

*Visiting Professor, University of Quebec

Address: P.O. Box 412, Ville de Laval, Quebec, Canada
The present study was undertaken to compare the incidence of $N$. gonorrhoeae, $T$. vaginalis, and $C$. albicans in a selected group of juvenile delinquent girls aged 13 to 17 years with that in clinic and hospital cases of similar age groups, and in other girls aged 18 years or over.

\section{Material and methods}

Specimens from 4,804 females were received in the laboratory between January 1, 1970, and December 31, 1971 ; 3,334 came from hospitals and clinics, 984 from police cases aged 18 years or over, and 486 from the 'Centre d'Accueil Féminin, Montréal', a custodial institution for young girls aged 17 years or less. Of the last group, 334 (69 per cent.) were French speaking and 152 (31 per cent.) were English speaking. The girls are admitted to this centre by order of the juvenile court and are detained under the provincial Juvenile Delinquency Act for not more than 24 hours. During this period, an examination for venereal disease is performed by an authorized medical practitioner. The girls in custody may be juvenile offenders apprehended by the police for vagrancy, antisocial behaviour, or sex offences, or they may need care or protection after having fallen into bad company or having left home for various reasons such as promiscuity, psychological disorders, or family trouble, or they may be 'difficult' girls beyond the control of their parents. Except in the case of juvenile offenders, the girl's consent is obtained for the examination for venereal diseases. All the girls above 18 years of age who are in similar trouble are listed as police cases.

Specimens were taken from the urethra, vagina, or cervix, except in the case of the juvenile delinquents from whom only urethral and vaginal swabs were usually taken. They were sent to the laboratory in Stuart's transport medium (Difco). Specimens from the juvenile and police cases were received in the laboratory within 5 hours. Specimens from the hospitals, youth and gynaecology clinics of private organizations or physicians, and venereal disease clinics operated by the government were sent through the mail, and there was a significant delay in their reception. On an average 14 per cent. were received within 24 hours, 47 per cent. within 48 hours, 27 per cent. within 72 hours, and 12 per cent. after 72 hours. Soon after receipt of the specimens, two slides were prepared; one was examined under the microscope for the presence of typical flagellated trichomonads and 
the other was examined for typical gonococci after Gramstaining. The specimen was also inoculated onto ThayerMartin (1964), Kupferberg, Johnson, and Sprince (1948), and Sabouraud's culture media for the isolation of $N$. gonorrhoeae, $T$. vaginalis, and $C$. albicans respectively. The presence of $N$. gonorrhoeae was confirmed by biochemical reactions and the delayed fluorescent antibody test (Deacon, Peacock, Freeman, and Harris, 1959). That of C. albicans was confirmed by the formation of chlamydospores in corn meal agar (Difco) and by sugar assimilation tests.

Antibiotic sensitivity studies for $N$. gonorrhoeae were done on chocolate agar $15 \times 60 \mathrm{~mm}$. plates containing the following concentrations of antibiotics: chloramphenicol $(0.25 \mu \mathrm{g} . / \mathrm{ml}$.$) , chlortetracycline (0.12 \mu \mathrm{g} . / \mathrm{ml}$.), dextrosulphenidol $(0.25 \mu \mathrm{g} . / \mathrm{ml}$.), doxycycline $(0.1$ $\mu \mathrm{g} . / \mathrm{ml}$.), kanamycin (4.0 $\mu \mathrm{g} . / \mathrm{ml}$.), penicillin ( 0.2 i.u./ $\mathrm{ml}$.$) , and tetracycline (0.2 \mu \mathrm{g} . / \mathrm{ml}$.). Bacterial colonies were suspended in sterile physiological saline. Approximately $10^{6}$ bacteria from this suspension were plated onto one plate containing antibiotic and a control plate without antibiotic. Plates were read after overnight incubation at $37^{\circ} \mathrm{C}$. in the presence of 10 per cent. $\mathrm{CO}_{2}$.

\section{Results}

Tables I, II, and IV deal with the number of isolations from patients who were positive for either one, two, or three organisms studied. The same patient has been counted positive twice or thrice in these Tables if positive for any two or for all three of these organisms respectively. As a result, the figures in the horizontal 'Total' row represent the total number of isolations and not the number of positive patients. On the contrary, Tables III and V show the numbers of patients from whom the organisms were isolated either singly or in combination.
Incidence of infection according to age and language group amongst 486 juvenile delinquents

Of the 486 juvenile delinquents, 34 ( 7 per cent.) were positive for $N$. gonorrhoeae confirmed by culture and delayed fluorescent antibody techniques (Table I); 62 (12.8 per cent.) were positive for $T$. vaginalis and 91 (18.7 per cent.) for $C$. albicans. The incidence of $N$. gonorrhoeae in the Frenchspeaking girls was 5.4 per cent., and it was almost twice as high in the English-speaking group; the isolation of $T$. vaginalis was similar in the French and English-speaking groups; $C$. albicans was found more often in the former. At least one of the three micro-organisms was isolated from 31.8 per cent. of the $\mathbf{4 8 6}$ girls (Table III, overleaf).

Comparative study of 486 juvenile delinquents and 561 hospital cases of similar age

$N$. gonorrhoeae was isolated in 12 per cent. of the 561 hospital cases (Table II), but $T$. vaginalis and $C$. albicans were each found about twice as frequently in the juvenile delinquents as in the hospital cases. $N$. gonorrhoeae was also found in four other hospital cases not shown in the Table; one was aged 8, two 9, and one 12 years.

Table III shows that the percentage of cases in which $N$. gonorrhoeae was isolated alone was three times greater in the hospital series than in the juvenile delinquents. On the contrary, $T$. vaginalis and $C$. albicans were isolated singly twice as often from the latter. The incidence of $N$. gonorrhoeae amongst patients with trichomoniasis was similar (24.2 per cent.) in both groups. On the other hand, 13.2 per cent. of the hospital cases and 44.1 per

TABLE I Frequency of isolation of $\mathrm{N}$. gonorrhoeae, $\mathrm{T}$. vaginalis, and $\mathrm{C}$. albicans from 486 juvenile delinquents, according to age and language group

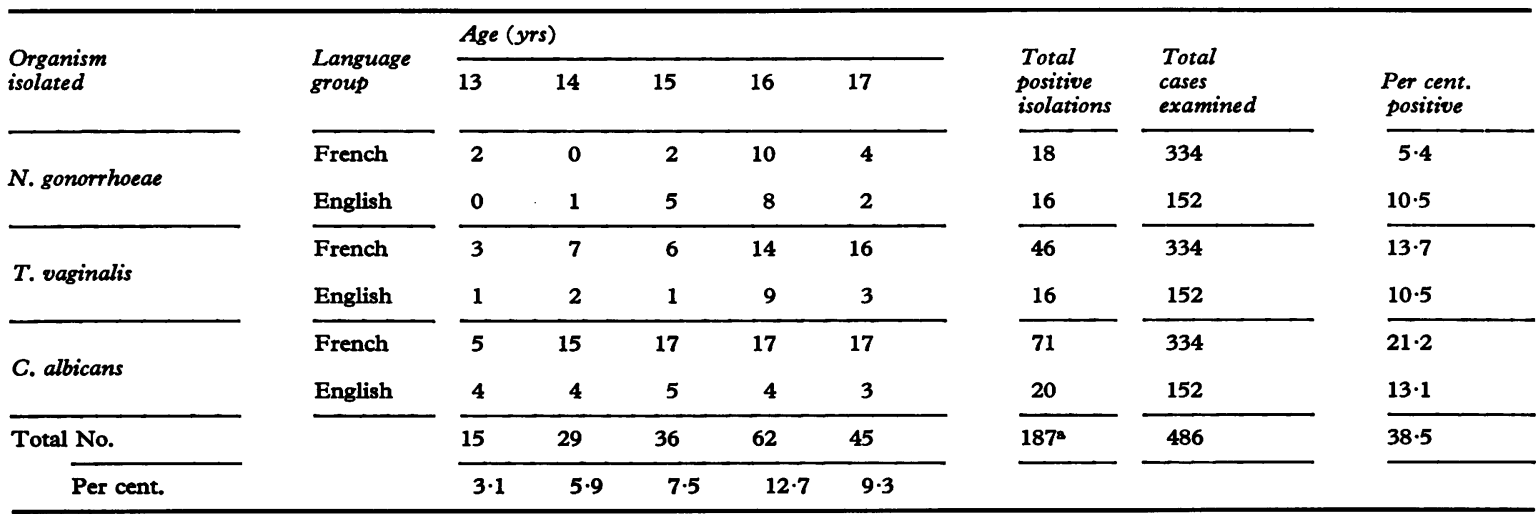

From 154 cases 


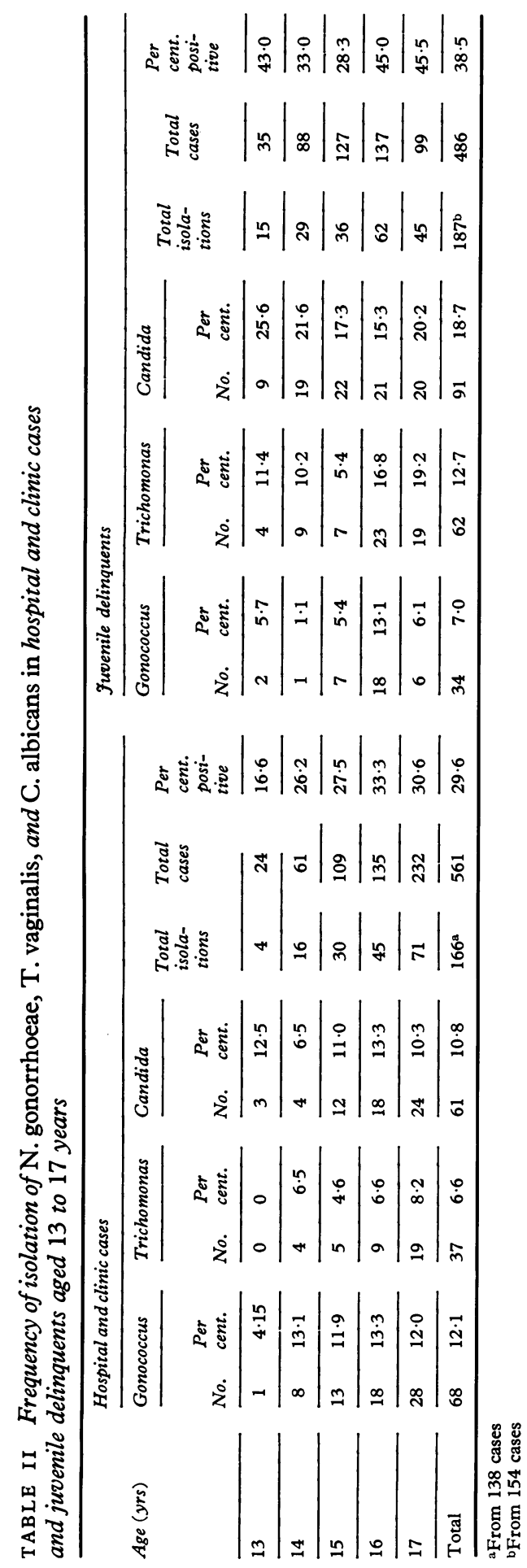

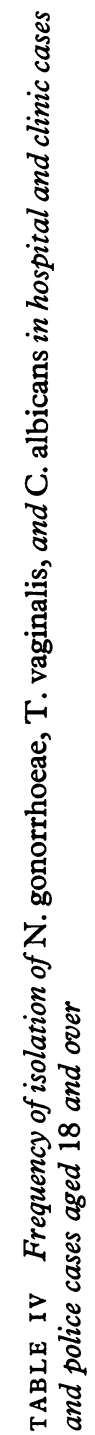

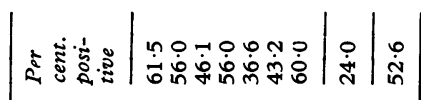

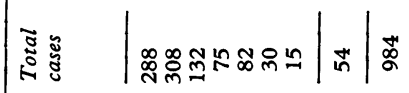

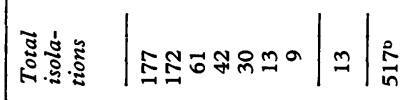

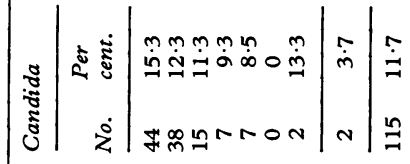

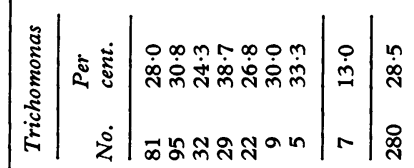

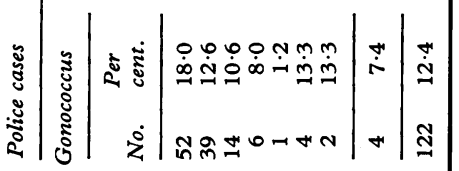

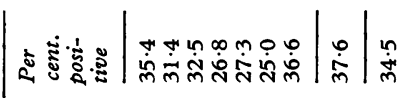

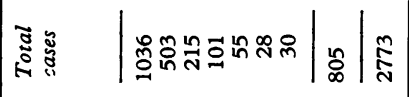

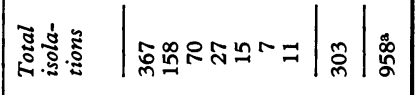

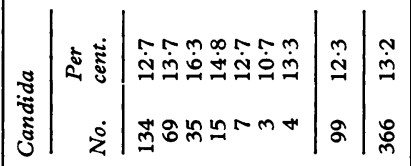

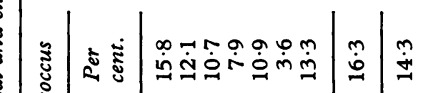
zं 
T ABLE II I Single and multiple isolations from hospital and clinic cases and juvenile delinquents aged 13 to 17 yrs

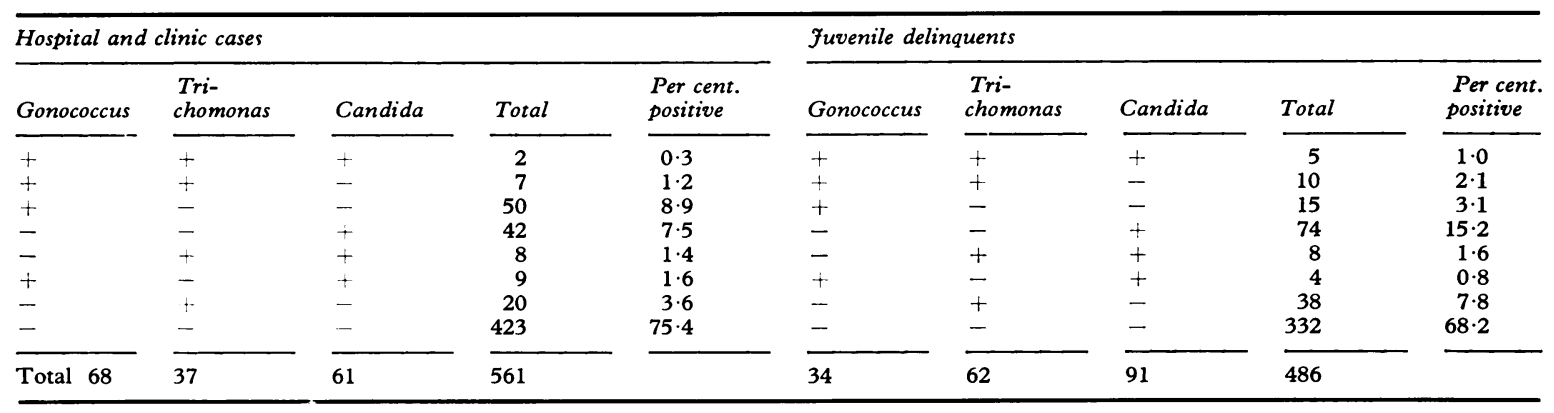

T A BLE V Single and multiple isolations in hospital and clinic cases and police cases aged 18 years and over

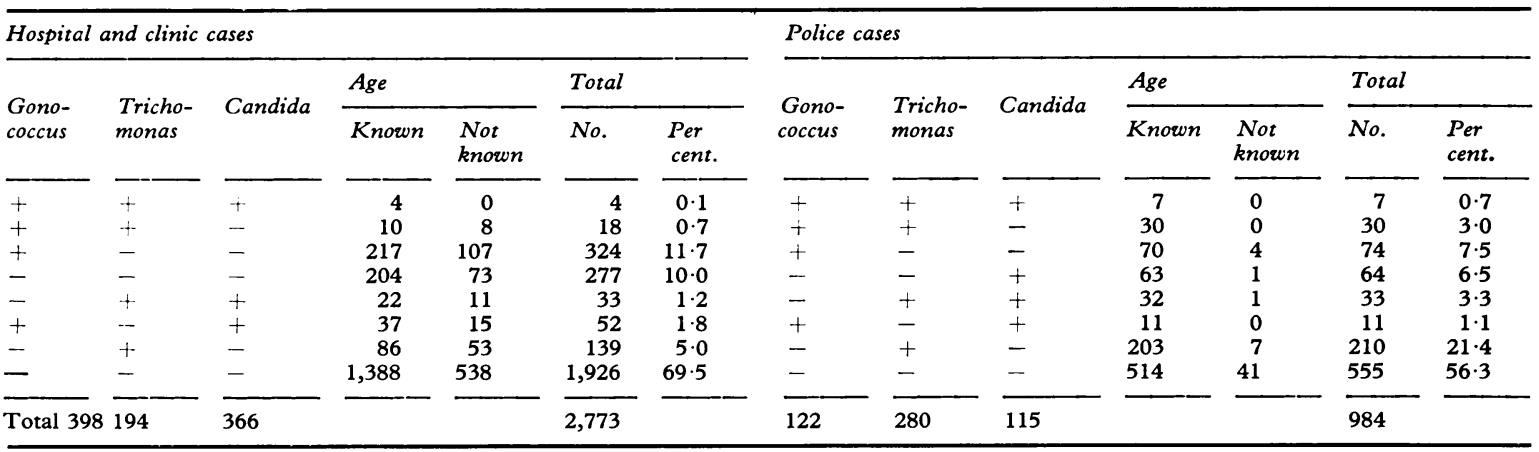

cent. of the juveniles infected with $N$. gonorrhoeae were also infested with $T$. vaginalis.

Comparative study of the 2,773 hospital cases and 984 police cases aged 18 years and over

Delinquent girls over 18 years of age were classed as police cases. Table IV shows that the overall percentages positive for $N$. gonorrhoeae and $C$. albicans were similar in the two series of cases, but $T$. vaginalis was four times more frequent in the police cases.

It is interesting to note that the percentage positive for $N$. gonorrhoeae alone was greater in the hospital cases than in the police cases (Table V), despite the fact that the hospital specimens were usually submitted through the mail.

\section{Sensitivity of strains of $\mathrm{N}$. gonorrhoeae to antibiotics}

None of the strains was resistant to chlortetracycline and dextrosulphenidol. As shown in Table VI, 43.8 per cent. of the 98 hospital strains, 16.7 per cent. of the sixty police strains, and 7.4 per cent. of the 27 juvenile strains tested showed reduced sensitivity to at least one of the seven antibiotics. 22.4 per cent. of the hospital strains were resistant to
$0.2 \mathrm{i} . \mathrm{u} . / \mathrm{ml}$. penicillin in comparison to 6.7 per cent. of the strains from police cases. None of the 27 strains from the juvenile delinquents was resistant to penicillin.

\section{Discussion}

Normal vaginal $\mathrm{pH}$ at and after puberty varies from 4 to 4.7 (Cohen, 1969). The most favourable vaginal $\mathrm{pH}$ for $N$. gonorrhoeae, $T$. vaginalis, and $C$. albicans is about $7.4,6$, and 5.4 respectively. Differences in vaginal $\mathrm{pH}$ which are due to various physiological changes may play a role in the prevalence of specific micro-organisms at different periods of life.

Dunkelberg, Skaggs, Kellogg, and Domescik (1970) in a study of 200 patients aged 12 to 67 years, of whom half were promiscuous and half were sexually conservative women exposed to gonococcal infection by their consorts, found a positivity rate of 8.5 per cent. for the gonococcus when it was the only organism isolated. Our findings in 4,318 hospital and police cases aged 13 to 69 years are similar, the average positivity rate being 9.3 per cent. The total positivity rates for $N$. gonorrhoeae and $T$. vaginalis in juvenile delinquents aged 13 to 17 was 7 and 12.7 per cent. compared with the 8.8 and 28.2 per cent. noted by 
TABLE VI Resistance pattern of $\mathrm{N}$. gonorrhoeae strains to different antibiotics

\begin{tabular}{|c|c|c|c|c|c|c|c|c|}
\hline$P$ & $C$ & $D$ & $T$ & $K$ & \multicolumn{4}{|c|}{ No. of N. gonorrhoeae strains resistant } \\
\hline $\mathbf{R}$ & 一 & 一 & - & - & 13 & 2 & 0 & 15 \\
\hline - & $\mathbf{R}$ & - & 一 & 一 & 5 & $\mathbf{0}$ & 1 & 6 \\
\hline - & - & 一 & $\mathbf{R}$ & - & - & 4 & 0 & 4 \\
\hline $\mathbf{R}$ & $\mathbf{R}$ & - & - & - & 2 & 0 & 0 & 2 \\
\hline $\mathbf{R}$ & $\mathbf{R}$ & $\mathbf{R}$ & 一 & 一 & 5 & 0 & 0 & 5 \\
\hline $\mathbf{R}$ & $\mathbf{R}$ & $\mathbf{R}$ & $\mathbf{R}$ & $\mathbf{R}$ & 1 & 0 & 0 & 1 \\
\hline- & - & $\mathbf{R}$ & $\mathbf{R}$ & - & 1 & 0 & 0 & 1 \\
\hline $\mathbf{R}$ & - & - & - & $\mathbf{R}$ & 0 & 2 & 0 & 2 \\
\hline \multicolumn{5}{|c|}{ Total resistant/total tested } & $42 / 98$ & $10 / 60$ & $2 / 27$ & $54 / 185$ \\
\hline \multicolumn{5}{|c|}{ Per cent. resistant to at least one antibiotic } & $43 \cdot 8$ & $16 \cdot 7$ & $7 \cdot 4$ & $28 \cdot 2$ \\
\hline
\end{tabular}

$\mathbf{P}=$ penicillin, $\mathrm{C}=$ chloramphenicol, $\mathrm{D}=$ doxycycline, $\mathrm{T}=$ tetracyline, $\mathrm{K}=$ kanamycin, $\mathrm{R}=$ resistant, $-=$ sensitive Agents against which no resistance was observed (chlortetracycline and dextrosulphenidol) are not listed in this Table.

Gallagher (1970) in England. The rates for $N$. gonorrhoeae in police cases and hospital cases were similar and this may reflect the fact that the specimens received from the hospitals and clinics came mainly from promiscuous subjects. The positivity rate for $T$. vaginalis in the hospital cases was much lower than in the juvenile and police cases of the same age group (Tables II and IV). This can be explained by the fact that almost 40 per cent. of the specimens were not received until after a delay of 48 hours.

This delay was also responsible for a lower trichomonas/gonococcus ratio in this group than in the juvenile or police cases. A decrease in the percentage positive for $T$. vaginalis at the age of 15 , in both hospital and juvenile subjects, could not be explained. The high positivity rates for $T$. vaginalis and the gonococcus in police cases $(28.5$ and 12.4 per cent. respectively) in comparison with juvenile cases (12.7 and 7 per cent. respectively), the specimens having been received within 5 hours, prove that the former group is much more promiscuous than the latter and represents an important pool of infection. The Figure shows that the positivity rate for $T$. vaginalis increases from 13 to 17 years of age in juvenile cases; thereafter these will probably form part of the police cases, the curve being a prolonga- tion of that for the juveniles. The incidence of Candida in all four groups (juveniles, hospital cases aged 13-17 and 18 years or more, and police cases) does not seem to depend on promiscuity as does that of the gonococcus and the trichomonad.

Of the 122 police cases who had gonorrhoea, 30.3 per cent. also had trichomoniasis, compared with 44.1 per cent. of the 34 juvenile delinquents. Conversely, 13.2 per cent. of the 280 police cases who had trichomoniasis also had gonorrhoea in comparison to 24.6 per cent. of the 61 juveniles with trichomoniasis.

Antibiotic sensitivity studies showed that reduced sensitivity of $N$. gonorrhoeae to various antibiotics was frequent amongst the hospital and clinic patients, in 22.4 per cent. of whom the gonococcus showed resistence to $0.2 \mathrm{i}$.u. $/ \mathrm{ml}$. penicillin. On the other hand, only 6.7 per cent. of the strains from police cases were similarly resistant.

The continued high incidence of gonorrhoea in young delinquent girls suggests that reservoirs of infection may also be prevalent in schools and colleges, and that routine examinations at this level would be a useful control measure to protect the young population against the various sexually transmitted diseases. The presence of antibiotic resistant 
strains, specially in the young age group, should be ascertained in order to limit the propagation of these strains in society at large.

\section{Summary}

Urogenital specimens from 4,804 females, of whom 3,334 were seen in hospitals and clinics, 984 were police cases aged 18 years and over, and 486 were juvenile delinquents from a custodial institution aged 13 to 17 , were examined for the presence of $N$. gonorrhoeae, $T$. vaginalis, and $C$. albicans. 7 per cent. of the juvenile cases, 12.4 per cent. of the police cases, 12 per cent. of the hospital cases aged 13 to 17 , and 14.3 per cent. of hospital cases over 18 years of age were positive for $N$. gonorrhoeae. The incidence of $T$. vaginalis in these four groups was $12.7,28.5,6.6$, and 7 per cent. respectively. C. albicans was isolated with about the same frequency in these groups, except in the juveniles where it was slightly higher. The incidence of $N$. gonorrhoeae in English-speaking juveniles was almost double that in the French-speaking girls.

Of the 98 strains isolated from hospital patients that were tested, 43.8 per cent. showed reduced sensitivity to at least one of the seven antibiotics; 22.4 per cent. of these strains were resistant to 0.2 i.u. $/ \mathrm{ml}$. penicillin, compared with only $6 \cdot 7$ per cent. of the strains isolated from the police cases. None of the 27 strains isolated from the juvenile delinquents that were tested was resistant to penicillin.

The authors thank the Department of Social Affairs, Province of Quebec, for having provided the necessary facilities; also Dr Aimé Desforges and Miss Juliette Rivest of the 'Centre d'Accueil Féminin de Montréal', and Mrs. Anita Millet of Laboratory Services for their valuable collaboration in this study.

\section{References}

Catterall, R. D. (1971) Brit. F. vener. Dis., 47, 45

CoHEN, L. (1969) Ibid., 45, 241

CROWTHER, I. A. (1962) Lancet, 1, 1074

Deacon, W. E., Peacock, W. L., Freeman, E. M., and Harris, A. (159) Proc. Soc. exp. Biol. (N.Y.), 101, 322

Department of National Health and Welfare, OttaWa (1971) Epidemiol. Bull., 15, (10), 81

Dunkelberg, W. E. Jr., Skaggs, R., Kellogg, D. S., Jr., and Domescik, G. K. (1970) Brit. F. vener. Dis., 46, 187

GALLAGHER, E. (1970) Ibid., 46, 129

Hawkins, D. F. (1969) Brit. med. F., 2, 116

Jirovec, O., Breuindl, V., KuCERA, K., and SebeK, V. (1942) Z. Bakt. (abt. 1), 148, 338

King, A. J., MAsCall, W. N. ,and Price, I. N. O. (1936) Lancet, 2, 18

KuPfERBERG, A. B., Johnson, G., and SPRINCE, H. (1948) Proc. Soc. exp. Biol. (N.Y.), 67, 304
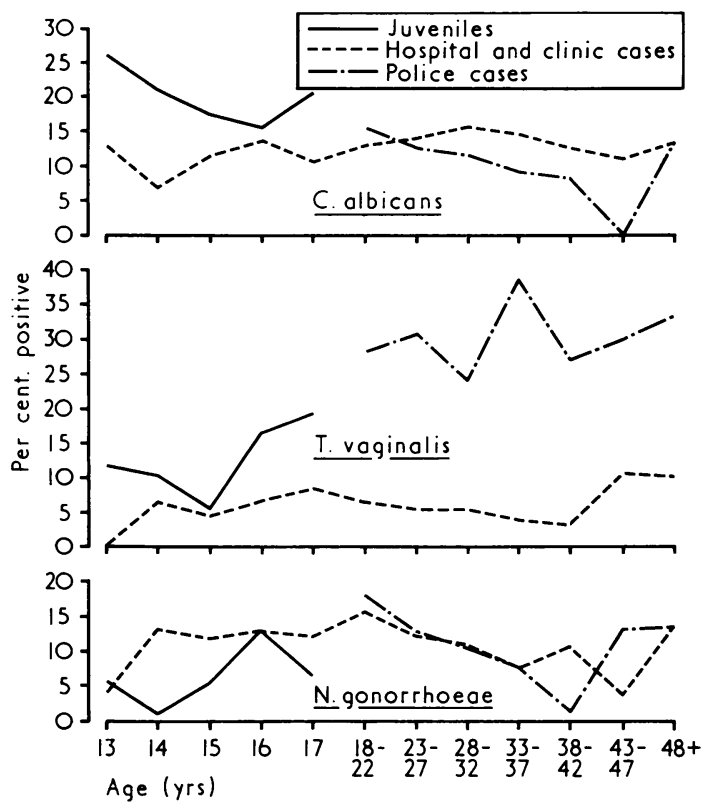

FIGURE Frequency of N. gonorrhoeae, $\mathrm{T}$. vaginalis, and $\mathrm{C}$. albicans in three groups of females, by age group

Thayer, J. D., and Martin, J. E. Jr., (1964) Publ. $\overrightarrow{\bar{O}}$ Hlth Rep. (Wash.), 79, 49

TsaO, W. (1969) Brit. med. F., 1, 642

\section{Infection génitale chez les jeunes délinquantes}

SOMMAIRE

Des échantillons provenant des organes génitaux de 4.804 femmes (dont 3.334 cas hospitaliers, 980 'cas de $\bigcirc$ police' âgées de 18 ans et plus, et 486 jeunes filles âgées $₹$ de 13 à 17 ans d'un centre d'accueil féminin) furento examinées dans le but de dépister la présence de Neisseria gonorrhoeae, de Trichomonas vaginalis et de Candida $\frac{7}{0}$ albicans. Neisseria gonorrhoeae fut trouvé chez 7 pour cent des jeunes (chez 12,4 pour cent des 'cas de police', $N$ chez 12 pour cent des cas âgés de 13 à 17 et chez 14,3 pour cent des cas âgés de 18 ans et plus dans les hôpitaux). 0 La fréquence de Trichomonas vaginalis fut, dans les $\underset{\omega}{N}$ mêmes groupes, respectivement, de 12,$7 ; 28,5 ; 6,6$ et 7 O pour cent. Candida albicans fut isolé avec à peu près la même fréquence dans chacun de ces groupes, sauf chez les jeunes où elle était plus élevées. Les jeunes anglophones $\$$ furent deux fois plus positives pour Neisseria gonorrhoeae que les francophones. 43,8 pour cent des souches isolées $\frac{T}{3}$ chez les patientes des hôpitaux qui furent examinées étaient résistantes au moins à un des 7 antibiotiques employés. 22,4@ pour cent de ces souches étaient résistantes à la pénicilline. $\mathbb{Q}$ 6,7 pour cent seulement des souches isolées des "cas de police" étaient résistantes à cet antibiotique. On ne trouva aucune souche résistante à la pénicilline parmi les 27 isolées 8 chez les jeunes qui furent examinées. 